\section{On the ground in the Gaza Strip}

$\mathrm{T}$

hroughout the Israeli offensive on Gaza, Sana Rajab and Mohamed

"Abu Abed" Mughaiseeb worked at the heart of the emergency health services run by Médecins Sans Frontières (MSF). Sana, a nurse, and Abu Abed, a doctor, are first and foremost Palestinians from the Gaza Strip. Every Gaza resident has suffered in this war, they explain.

It began on Dec. 27, 2008. "It was $11 \mathrm{am}$ when the bombing started. It was a Saturday," says Abu Abed. "Within hours, there were lots of casualties. It was chaos. We visited the hospitals to find out what the medical needs were. Because MSF had emergency stocks in the area, we were able to donate drugs and medical supplies."

Even as bombs continued to fall on Gaza City, the MSF medical team reopened its postoperative clinic. The clinic took in casualties who had undergone emergency operations in hospitals and needed medical follow-up. "Because of the bombings it was very difficult for patients and MSF staff to move around," says Sana. "We gave our colleagues emergency medical kits so that they could give medical assistance right at the heart of their neighbourhoods."

Despite the intense fighting, the MSF teams assisted 60 to 70 patients every day in Gaza City. The patients included injured people who needed medical treatment, as well as many othdic surgery. ing. It was very painful." ers suffering from "normal" or chronic illnesses who could not access their regular treatments because of the war.

Twenty-two days after the Israeli offensive began, a ceasefire allowed MSF teams to administer more aid across the Gaza Strip. A tent-based hospital was set up to provide secondary surgical care and follow-up to those injured during the fighting. Within 2 weeks, MSF doctors had operated on about 40 people, many suffering from burns and infected wounds, some requiring orthope-

Today, Sana works with mobile teams that visit areas worst affected by the violence, and various health care facilities, where she identifies and refers patients to the MSF hospital. Abu Abed coordinates MSF medical programs in the Gaza Strip. Both remain shocked at the trauma suffered by the Palestinian population.

Sana talks of the time she spent listening at length to an injured man. "He had been shot in the arm. Three of his brothers and his only sister had been killed. He couldn't stop talking. I listened to him, and then kept on listen-

Abu Abed says, "There are stories which are really difficult to hear. During the bombings, the Israeli army decreed a daily 3 -hour ceasefire. There were children who used to wait for this relative calm to go to the toilet! Can

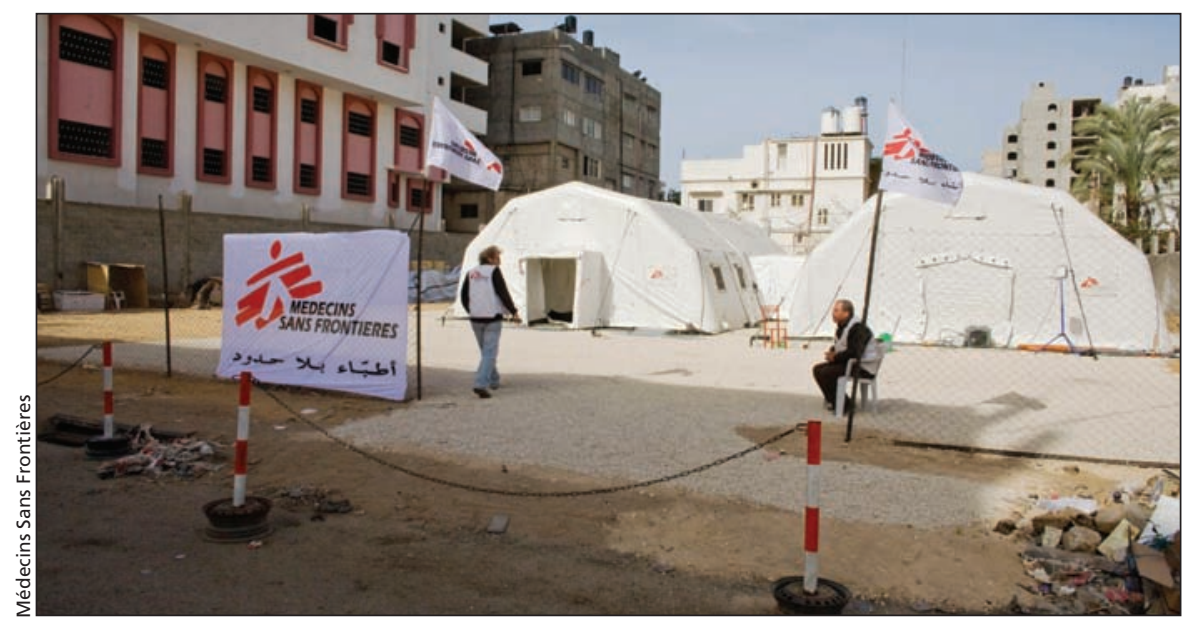

A tent-based hospital was set up to provide secondary surgical care and follow-up to those injured in the war.

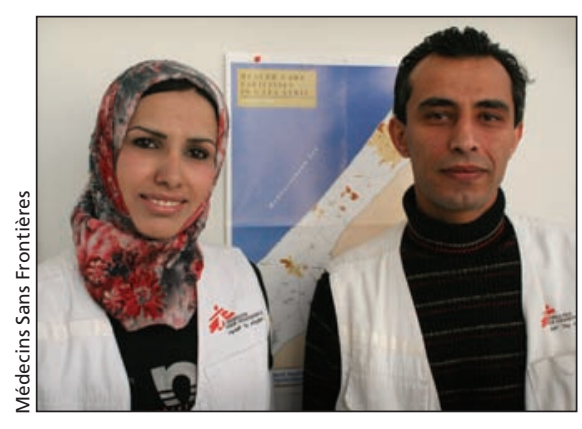

Sana Rajab and Mohamed "Abu Abed" Mughaiseeb, a nurse and doctor from the Gaza Strip, say every Gaza resident suffered in the war.

you imagine a child of 5 , so terrorized that he's holding it in and asking his mother when the lull in the fighting will be so he can go to the toilet?"

The memories keep on coming. The conversation is animated. "If we begin to remember every tragic story, we'll never stop," says Sana.

Today, war has given way to the aftermath of war - to physical and psychological wounds. The MSF mental health program, which has been in place in Gaza for several years, is now offering psychological support for emergency medicine staff, who found themselves on the front line providing emergency war aid.

"Young or old, rich or poor, black or white, Muslim or any other religion, we've all been affected," Abu Abed says. "So many people have been injured. Others have lost a brother or a friend, and still others have had their homes destroyed. ... Every inhabitant of the Gaza Strip, without exception, has suffered in this war." - François Dumont, Gaza, Palestine

DOI:10.1503/cmaj.090285

CMAJ invites contributions to "Dispatches from the medical front," which provide eyewitness glimpses of medical frontiers, whether defined by location or intervention. Submissions should be forwarded to: wayne.kondro @ cmaj.ca. 